\title{
ANALYSIS OF WOOD PRODUCTS FROM AN ADDED VALUE PERSPECTIVE: THE URUGUAYAN FORESTRY CASE
}

\author{
Andrés Dieste $^{1, \star}$, María Noel Cabrera ${ }^{1}$,Leonardo Clavijo ${ }^{1}$, Norberto Cassella ${ }^{1}$
}

\begin{abstract}
Uruguay has a forest resource of 1 million ha plantation of fast-growing eucalyptus and pine. Short-fiber pulp is the country second export product in value, but there is also a significant production of plywood and graded kiln-dried timber from both species, used mainly for appearance applications. However, the value chain of the wood industry is not yet fully developed, particularly for pine. This study classified different existing and potential wood products using added value as criteria, calculated at the industry level by adopting a system of inputs and outputs. Hypothetical plants to manufacture these products were technical and economically analyzed: thermally modified timber, cross laminated timber, laminated veneer lumber, pine timber, bleached Eucalyptus kraft pulp, pine bleached chemical thermo-mechanical, medium density fiberboards, oriented strand board and a power plant fueled with forest biomass. The data used for this study was obtained from the final project of undergraduate engineer students of the Faculty of Engineering, Universidad de la República, Uruguay, except for the eucalyptus pulp mill, which was proposed by the authors. The results showed that wood products obtained from logs that are the main objective of the plantation presented a higher added value than those manufactured from forest residues, thinnings or chips from the sawmilling industry. Solid wood products for appearance or structural applications are at the top of added value list, considering value added per product, unit of biomass or unit of forest land per year.The integration of the value chain of the products analyzed, linking solid wood products with panels or pulp, has the potential to boost the addition of value of the forest biomass in Uruguay.
\end{abstract}

Keywords: Bioeconomy, forest plantations, forest products, solid wood products, wood industry.

\section{INTRODUCTION}

Due to policies implemented at the end the last century, Uruguay has a forest resource of 1 million ha of fast-growing species, divided in Eucalyptus spp. (70\%) and Pine spp. (30\%); in addition, the largest portion of this forest mass is located within a radius between $400-500 \mathrm{~km}$ from the port of Montevideo, main outlet of Uruguayan exports (Dirección General Forestal - MGAP, 2016). The country currently harvests 14 million $\mathrm{m}^{3} /$ year, from which $70 \%$ are Eucalyptus spp. Pulp logs, mainly composed of E. grandis, E. globulus and E. dunnii. The remaining $30 \%$ is divided in $2.7 \times 10^{6} \mathrm{~m}^{3}$ Eucalyptus spp. for fuelwood, $700 \times 10^{3} \mathrm{~m}^{3}$ E. grandis for sawlogs, and $850 \times 10^{3} \mathrm{~m}^{3}$ Pinus taeda for sawlogs (Boscana and Boragno 2017). However, for the period 20102030 it was estimated that a minimum of 2 million $\mathrm{m}^{3}$ of pine wood would annually reach industrial standards for saw- or pulp logs, but are not harvested, due to lack of investment in industrial capacity (Dieste 2012).

The establishment of this forest resource in Uruguay is recent, with the bulk of the plantations having taken place in the last decade of the XX century. Consequently, the industrial system to efficiently transform this biomass in products is currently being developed. Presently, the main wood product is short-fiber pulp; in addition, plywood and kiln dried timber is also produced, albeit in much lesser volume. The eucalyptus pulp industry has experienced a clear development in Uruguay. Two state-of-the-art pulp mills, UPM and Montes del Plata, produce $2.6 \times 10^{6}$ air-dried ton per year, which in 2016 represented the second most important country export product in value (Uruguay XXI 2017). In addition, the industrial capacity for eucalyptus planted to produce solid wood products is adequate to process the plantations output (Dieste 2014); furthermore, the

${ }^{1}$ Instituto de Ingeniería Química, Facultad de Ingeniería, Universidad de la República, Montevideo, Uruguay.

•Corresponding author: andresdieste@fing.edu.uy

Received: 02.11.2017 Accepted: 09.12.2018 
short-fiber pulp industry is a potential destiny for logs that do not reach the sawing grade (URUFOR 2016). For the pine forestry sector, the situation is different: the installed industrial capacity is insufficient and there is no market for logs of small diameter, pulp logs and even small-diameter sawlogs (Dieste 2014). Consequently, thinnings, a removal of trees from the plantation to improve the growing conditions of the remaining ones, are only marginally harvested and installed pine sawmills absorb the cost of processing lower-grade wood.

In recent years, governments around the world have given increasing attention to the development of an economy based on biological resources, as opposed to one based on fossil resources (Sillanpää and Ncibi 2017a). A key aspect of a bioeconomy is that profitability should be achieved under environmentally sustainable industrial operations, adding more complexity to the economic interaction (Sillanpää and Ncibi 2017b). The sophisticated use of a forest resource to obtain materials, chemical and energy is indicated as a central aspect of the development of a bioeconomy (Karvonenet al. 2017).

The development of an industry to process the Uruguayan forest resource depends on global market conditions, since its size is disproportionally larger than the capacity of the country to consume forest products (pulp, timber, boards, among others). Clearly, most of the production must be exported. In addition, the capital equipment to transform wood has been mainly supplied by third countries, as well as some raw materials, such as chemicals and adhesives. In a simplified scenario, the factors that determine the installation of industries in Uruguay are the availability of the forest resource, obtained from plantations; the cost of local services, namely energy, transport, and labor; and the tax extracted for revenues. The wood industry is incipient and there are many potential products that could be manufactured. The technical and economic feasibility of different technologies to add value to an established forest biomass has been discussed elsewhere (Clark 2004, Dhubháin et al. 2009, Goodison et al. 2013, Kato 1999, Spelter et al. 1996). This article analyzes different wood products using added value as classification criteria, distinguishing three levels where value could be added: product, biomass and forest land.

\section{METHODOLOGY}

The method used to calculate added value is taken from Sathre and Gustavsson (2009). It is a process-level analysis that considers inputs, material and energy, and outputs, products; the value is added to the products by means of labor and capital. Therefore, the economical added value could be decomposed in the following elements: 1) salaries, 2) service of fixed capital, and 3) the operation benefits.

The premises considered for the study scenario were 1) products fabricated using mature technologies that consume wood in its primary forms; 2) products feasible to be fabricated in Uruguay; 3 ) focus on pine wood, with eucalyptus products used as reference. The products selected are the result of an analysis that combined the forest supply of Uruguay with the current wood products market offer (Goodison et al. 2013, Ramage et al. 2017, Sathre and Gustavsson 2009, Wegner et al. 2009). The fabrication of lignin-based products, such as wood adhesives, or the production of bio-plastics, were also considered, but were not included due to lack of information to design the industrial process in detail. The data for this analysis was obtained from different undergraduate projects of the Faculty of Engineering of the Universidad de la República, written as a requirement to obtain the engineer degree(Aguirre et al. 2017, Barragán et al. 2016, Borche et al. 2012, Brizolara et al. 2015, Caamaño et al. 2016, Cabrera et al. 2018, Fierro et al. 2009, García et al.2018, Méndez et al. 2016), except for the bleached eucalyptus kraft pulp plant, which was conceived by the authors using public information. In addition, this methodology to estimate added value was previously tested for the Uruguayan wood industry in the undergraduate project of Anzolabehere and Nan (2014).

The analysis was performed under the hypothesis that forest products could be classified according to objective of the forest plantation: central products and peripherical products. The first groups are products obtained from logs that are the principal aim of the forest plantation, such as saw- and veneer logs of minimal apical diameter larger of $20 \mathrm{~cm}$, and also Eucalyptus spp. pulp logs of minimal apical diameter of 8 $\mathrm{cm}$. The second group of forest products are obtained from forest thinnings or residues of central products processing, such as chip, sawdust or bark. This classification tried to reflect the present scenario of the Uruguayan forestry industry, different from an established forest resource that, for an extended period, provides a relatively constant flow of products, as it could arguably be the situation of Scandinavian countries (Sathre and Gustavsson 2009). This study considered four type of forest products: E. grandis pulp logs and sawlogs, and P. taeda pulplogs and sawlogs. For each product, a flow of annual fiber was defined per unit of surface, 
in terms of mean annual wood volume increment (MAI) (Cubbage et al. 2014). The proportion of $P$. taeda sawlogs from the total forest pine output was taken as $80 \%$ (Bussoni and Cabris 2010), and the rest was considered pulpwood. Clearly, thinnings are executed before the rotation is finished; however, as the land is occupied until clear cut, the duration of the rotation for $P$. taeda pulp logs was considered at 22 years (Table 1).

Table 1: Mean annual volume increment for selected forest products of Uruguayan plantations.

\begin{tabular}{lcc}
\hline Forest product & $\begin{array}{c}\text { Rotation } \\
\text { (years) }\end{array}$ & $\begin{array}{c}\text { MAI } \\
\left(\mathbf{m}^{\mathbf{3}} / \mathbf{h a} / \mathbf{y e a r}\right)\end{array}$ \\
\hline E. grandis pulplogs & 10 & 28 \\
E grandis sawlogs & 20 & 25 \\
$P$. taeda sawlogs & 22 & 14 \\
P. taeda pulplogs & 22 & 4 \\
\hline
\end{tabular}

In addition, the average flow of forest residue after clear cut of $E$. grandis saw- and pulp logs and $P$. taeda saw- and pulp logs was considered 6 ton/ha/year at $40 \%$ (wet basis), equivalent to a lower heat value of $55 \mathrm{GJ} /$ ha/year (PROBIO 2013).

The wood products industries analyzed, that used central forest products as raw material, were thermally modified timber (TMT), cross laminated timber (CLT), laminated veneer lumber (LVL), pine timber, and bleached Eucalyptus kraft pulp (BEKP), and the wood products, that used peripherical forest products as fiber source, were pine bleached chemical thermomechanical (BCTMP), medium density fiberboards (MDF), oriented strand board (OSB) and a power plant that generates electric energy from steam, using forest biomass as fuel. Only three examples of the selected industries are currently operating in Uruguay: pine timber mill, BEKP and the power plant. The other industries were selected because they were considered to have the potential to be developed in Uruguay, and there was enough available information on the technology for undergraduate students to design the process to the level of a technical and economic feasibility project. The analysis presented in this study is hypothetical, since the data does not represent actual operations. All plants studied were economical feasible, rendering profits, except for the power plant. The investment considered is the total capital cost, obtained by adding the direct costs (total equipment cost, equipment installation, electrical installations, land, civil work, ground improvement, and services), the indirect costs (engineering and supervisor, and construction expenses), the contractor's fees, the insurances and the working capital (Anaya et al. 2016).

The value of inputs for this study presented perhaps the greatest challenge to the authors, since most of the proposed industries do not currently exist in Uruguay, and information had to be estimated by direct inquires by the students or the authors. The research, mainly conducted by the students, was as comprehensive as possible. The price of wood fiber was presented per cubic meter at the processing facility considering both species available in Uruguay for industrial purposes, Pinus taeda and Eucalyptus grandis, in two formats, pulplogs and sawlogs. In addition, the price of pine green boards was obtained by local suppliers. The value of these products had to be estimated from several sources, since the Uruguayan market is still developing and there are no publications that summarize the information. The price of electric energy was considered at 99 USD/ MWh, including the connection cost currently charged to large consumers. The cost of adhesives was obtained by international suppliers, since Uruguay does not produce adhesives for the wood industry. The exchange rate was considered 28 Uruguayan Pesos (Uy\$) per American dollar (USD), and total investment was corrected by inflation to July 2017 (Table 2).

The value of outputs were FOB prices at the port of Montevideo, Uruguay, and therefore the analysis includes the cost of transporting the product from the plant to the port (FAO 2017). In Uruguay, forest industries are approximately $400 \mathrm{~km}$ from Montevideo, and the reference cost of the internal freight for a 50-feet-container truck and a 28-ton truck is tabulated at 1,370 USD and 1,200 USD, respectively (Dirección Nacional de Transporte 2015). The wood product prices were taken from FAOSTAT (FAO 2017) and from international suppliers. The value of electric energy was taken for the actual price that the local electricity company pays for biomass energy (UTE 2011) (Table 2). 
Table 2: Values of inputs and outputs considered (cost of raw materials at the operation plant).

\begin{tabular}{|c|c|c|}
\hline Input & \multicolumn{2}{|c|}{ Unit (USD/unit) } \\
\hline Pine sawlogs & $\mathrm{USD} / \mathrm{m}^{3}$ & 40 \\
\hline Pine pulplogs & $\mathrm{USD} / \mathrm{m}^{3}$ & 25 \\
\hline Pine green timber (medium grade) & $\mathrm{USD} / \mathrm{m}^{3}$ & 160 \\
\hline Pine green timber (high grade) & $\mathrm{USD} / \mathrm{m}^{3}$ & 200 \\
\hline Eucalyptus sawlogs & $\mathrm{USD} / \mathrm{m}^{3}$ & 60 \\
\hline Eucalyptus pulplogs & $\mathrm{USD} / \mathrm{m}^{3}$ & 55 \\
\hline Adhesive PF resin ( $51 \%$ solid content $)$ & $\mathrm{USD} / \mathrm{t}$ & 900 \\
\hline Adhesive UF resin ( $67 \%$ solid content) & $\mathrm{USD} / \mathrm{t}$ & 645 \\
\hline Adhesive pMDI & $\mathrm{USD} / \mathrm{t}$ & 1,930 \\
\hline Wax ( $50 \%$ solid content $)$ & $\mathrm{USD} / \mathrm{t}$ & 1,440 \\
\hline Structural adhesives (polyurethane) & $\mathrm{USD} / \mathrm{t}$ & 11,000 \\
\hline Pulping chemicals (BEKP) & $\mathrm{USD} / \mathrm{ADT}$ & 40 \\
\hline Pulping chemicals (BCTMP) & USD/ADT & 100 \\
\hline 50 -feet-container internal freight $(400 \mathrm{~km})$ & UDS/container & 1,370 \\
\hline 30-ton-truck internal freight $(400 \mathrm{~km})$ & USD/truck & 1,200 \\
\hline Electricity & USD/MWh & 99 \\
\hline Output & Unit & $\begin{array}{l}\text { Value } \\
\text { SD/unit) }\end{array}$ \\
\hline Pine TMT & USD $/ \mathrm{m}^{3}$ FOB Montevideo & 770 \\
\hline CLT & $\mathrm{USD} / \mathrm{m}^{3}$ FOB Montevideo & 950 \\
\hline LVL & $\mathrm{USD} / \mathrm{m}^{3}$ FOB Montevideo & 420 \\
\hline Pine KD timber & $\mathrm{USD} / \mathrm{m}^{3}$ FOB Montevideo & 280 \\
\hline Pine MDF & $\mathrm{USD} / \mathrm{m}^{3} \mathrm{FOB}$ Montevideo & 280 \\
\hline Pine OSB & $\mathrm{USD} / \mathrm{m}^{3} \mathrm{FOB}$ Montevideo & 260 \\
\hline BEKP & USD/ADT FOB Montevideo & 500 \\
\hline Lignosulphonates & U\$D/ton FOB Montevideo & 650 \\
\hline Pine BCTMP & USD/ADT FOB Montevideo & 450 \\
\hline Electricity & $\mathrm{USD} / \mathrm{MWh}$ & 87 \\
\hline
\end{tabular}

Cross-laminated timber are structural panels constructed by orthogonally gluing layers of timber boards, that usually are finger-jointed to achieve the desired length. CLT are massive assemblies of wood, used mainly as structural construction components in multi-story timber buildings (Ramage et al. 2017, Wilson and Taylor 2010). The proposed plant would produce $30 \times 10^{3} \mathrm{~m}^{3}$ of CLT of 3,5 and 7, $25 \mathrm{~mm}$-thick layers, according to client specifications, and $3 \times 16 \mathrm{~m}$ (width $\mathrm{x}$ length), to be consumed locally and exported to the region. The fiber requirement would be $44 \times 10^{3} \mathrm{~m}^{3}$ of classified green pine timber of medium grade, avoiding major structural defects, rendering a conversion efficiency factor from dry timber to CLT panel of $85 \%$. Green timber would be dried at the plant. The layers would be pneumatically pressed, using cold-curing polyurethane as adhesive (García et al.2018) (Table 3).

The thermal modification of wood allows in one process to increase dimensional stability and durability of wood (Batista et al. 2016), in addition, it is particularly relevant for Eucalyptus, which is not impregnable. Thermally modified timber (TMT) is usually used to manufacture facades to cover building walls, decks, windows and doors for external use, saunas, among other products. The thermally modified plant would consume green pine timber of high grade from local sawmills, to produce $10 \times 10^{3} \mathrm{~m}^{3}$ of thermally modified timber and $13.3,3 \times 10^{3} \mathrm{~m}^{3}$ of kiln dried (KD) timber. The thermal modification plant was a series of drying kilns and rectors for wood modification, that heated KD timber, using a thermal oil boiler with woody biomass as fuel, to a maximum of $250{ }^{\circ} \mathrm{C}$. High-grade timber would be required to minimize losses due to treatment defects; even so, in a conservative scenario, it is considered that only $40 \%$ of the pine lumber bought would be destined for modification, with the rest being sold as KD timber (Barragán et al. 2016)(Table 3). 
The pine timber mill proposed would produce $40 \times 10^{3} \mathrm{~m}^{3} /$ year of a combination of products: clear boards $(20 \%)$, finger-jointed boards (40\%), and low-grade packaging timber (30\%), in a proportion of $20 \%, 40 \%$ and $30 \%$, respectively. In addition, the mill would generate electric energy, $20 \mathrm{GWh}$ sold to the Uruguayan grid. The fibre consumption would be roughly $100 \times 10^{3} \mathrm{~m}^{3}$ of pine sawlogs obtained by clear cut at the end of the forestry cycle, 22 years. The plant consists in a sawmill, kiln drying facilities to process the whole sawmill production, a cogeneration unit with a biomass fuelled boiler, and a remanufacture plant, including planning, cutting-to-length, optimization, and finger-jointing, among other wood working operations. The production would be exported (Fierro et al. 2009) (Table 3).

LVL beams is an engineered wood product, used extensively in North America for the wood construction industry, which has been regionally tested for Eucalyptus grandis wood (Saviana et al. 2009). Beams are composed of multilayers of rotary-peeled veneers, with their faces parallel to the wood grain, glued with PF resins and hot pressed. The limiting factor in the beam dimension is the size of the press. LVL beams allow the transformation of wood with low mechanical properties into high-strength construction product (Spelter et al. 1996). The proposed LVL mill would produce $80 \times 10^{3} \mathrm{~m}^{3}$ of beams from $157 \times 10^{3} \mathrm{~m}^{3}$ of pine and eucalyptus sawlogs, 80 and $20 \%$, respectively. The beams of section $45 \times 406 \mathrm{~mm}$, equivalent to $13 / 4 \times 16$ inches, would be produced in two lengths: 5.4 and $6.1 \mathrm{~m}$, equivalent to 18 and 20 feet, respectively, destined to be sold as construction element for the global market (Caamaño et al. 2016) (Table 3).

Bleached eucalyptus kraft pulp (BEKP)main application as raw material for the production of tissue and printing paper (Fardim et al. 2013). Kraft pulping is a chemical process that produces cellulose pulp by dissolving lignin and hemicelluloses in a strong alkaline solution of active compounds $\mathrm{NaOH}$ and $\mathrm{Na}_{2} \mathrm{~S}$; once pulp is obtained, it is bleached to increase its brightness (Gullichsen and Paulapuro 1999). The BEKP mill foreseen for this study would produce $1,000 \times 10^{3} \mathrm{ADT} / \mathrm{year}$, the minimum size for these units (Bajpai 2015). The required forest land to supply the plant would be $133 \times 10^{3}$ ha, considering that such a mill would consume annually $3,7 \times 10^{6} \mathrm{~m}^{3}$ of Eucalyptus spp. fiber, according to the data for the existing mills in Uruguay (Boscana and Boragno 2017), and that $E$. grandis grows in Uruguay at $28 \mathrm{~m}^{3} / \mathrm{ha} /$ year, with a forest rotation of 10 years (Cubbage et al. 2014). The bleaching technology would be elementary chlorine free (ECF), with low consumption of chlorine compounds. The chemical input was estimated assuming that the production of 1 ton of BEKP requires pulping chemicals that cost 35-40 USD/ADT (Onarheim et al. 2016, Rasmussen 2012). The proposed plant produces an excess of energy that would be sold to the Uruguayan electrical grid at $87 \mathrm{USD} / \mathrm{MWh}$ (UTE 2011) (Table 3).

The production of pine bleached chemical thermomechanical pulp (BCTMP) is feasible even in small or medium size, with a lower level of investment, estimated at 850 USD/ADT year, in opposition to the 1,500 to 2,000 USD/ADT required for BEKP. BCTMP is a flexible product that can be used in printing, tissue papers and board, as a filler pulp (10 to $30 \%$ ) (Fardim et al. 2013), which allows a cost reduction. The proposed plant considered had a production of $130 \times 10^{3}$ ADT, with a fresh-wood consumption of $277 \times 10^{3}$ ton/year, well within the resources of pine wood in Uruguay. The product is electro-intensive but the wood yield is very high and chemical consumption is low (Ayroud 1997). It is considered that the produced BCTMP would be marketed regionally as filler pulp, substituting chemical pulp in non-integrated paper mills. The plant produces 23,400 ton/year of lignosulphonates. The plant consumes $126 \mathrm{GWh}$, and generates $29 \%$ and $30 \%$ by wind and cogeneration, respectively, to reduce the value of electric energy to 62 USD/MWh (Cabrera et al. 2018) (Table 3).

Medium density fiberboards (MDF) are panels made with wood fibers, obtained by mechanical means from wood chips, glued with phenol-formaldehyde resins and formed in a continuous hot press (temperature around $200^{\circ} \mathrm{C}$ ). They are extensively used in the furniture industry, and in moldings for room decoration. They can be easily machined and covered by coatings and paints. The proposed plant would fabricate $300 \times 10^{3} \mathrm{~m}^{3}$ of MDF panels from $557 \times 10^{3} \mathrm{~m}^{3}$ of pine pulp logs obtained from thinnings. Due to the relatively high capital cost, a large mill was designed to benefit from economy of scale. Panel thickness would vary from 3 to $30 \mathrm{~mm}$, according to client specifications. The selected glue would be urea-formaldehyde (UF). The mill would consume $0.44 \mathrm{MWh}$ of electric energy per $\mathrm{m}^{3}$ of MDF; in addition, due to thermal energy requirements, cogeneration is not economically feasible (Aguirre et al. 2017, Méndez et al. 2016) (Table 3).

Oriented strand boards (OSB) are composite wood panels fabricated with log flakes disposed in layers oriented by mechanical means and glued with phenol-formaldehyde resins and polymeric diphenyl methane diisocyanate (pMDI) in a hot-press. OSB are extensively used in the construction industry for flooring, ceilings, sheathing in walls, lining, among other applications. The density of the panels is adjustable within limits during pressing. Even though particles are large, limiting contact surface, pMDI, the standard for the industry, is expensive in Uruguay and increases the operating cost of the mill. The proposed mill would produce $150 \times 10^{3}$ 
$\mathrm{m}^{3}$ of OSB board, with a fibre consumption of $300 \times 10^{3} \mathrm{~m}^{3}$ of pine pulp logs, obtained by thinnings (Brizolara et al. 2015) (Table 3).

The proposed power plant would produce annually $165 \times 10^{3} \mathrm{MWh}$, fuelled by $144 \times 10^{3}$ ton/year forestry biomass. The plant would burn the biomass to produce gas, which would be burned in a torsional chamber to produce $67 \mathrm{ton} / \mathrm{h}$ of superheated steam $\left(485^{\circ} \mathrm{C}\right)$. The steam would be used to produce electric energy by means of a steam turbine connected to a generator. The plant would not condensate the steam in an associated process, but in an air-condenser. The electricity would be sold to the Uruguayan electrical grid. This is the only project selected which was estimated economically not feasible (Borche et al. 2012). It was included to have a baseline for one of the primary uses of woody mass. It should be pointed out that Uruguay does not have fossil fuels, and air-dried wood, at 5 USD/GJ, is the cheapest fuel available for thermic energy (Dieste et al. 2016)(Table 3).

Table 3: Wood products: production, fibre requirements, format, energy input and forestry land requirements.

\begin{tabular}{|c|c|c|c|c|c|c|c|c|}
\hline \multirow{3}{*}{$\begin{array}{l}\text { Forest } \\
\text { product }\end{array}$} & \multirow{3}{*}{$\begin{array}{l}\text { Wood } \\
\text { product }\end{array}$} & Production & Fibre & & & \multicolumn{3}{|c|}{ Electricity Land Investment } \\
\hline & & \multirow{2}{*}{\multicolumn{2}{|c|}{ unit $x 1000$ format }} & \multirow{2}{*}{\multicolumn{4}{|c|}{1000}} & \multirow[b]{2}{*}{$\mathrm{USD}^{10} 0^{6}$} \\
\hline & & & & unit & $\mathbf{x 1 0 0 0}$ & GWh/year & & \\
\hline \multirow[t]{7}{*}{ Central } & CLT & $\mathrm{m}^{3} /$ year & 30 Boards & $\mathrm{m}^{3} /$ year & 44 & 8 & 6 & 24 \\
\hline & Pine TMT & $\mathrm{m}^{3} /$ year & 10 Boards & $\mathrm{m}^{3} /$ year & 27 & 3 & 4 & 24 \\
\hline & LVL & $\mathrm{m}^{3} /$ year & $80 \operatorname{Logs}$ & $\mathrm{m}^{3} /$ year & 157 & 24 & 10 & 68 \\
\hline & Pine & & & & & & & \multirow{2}{*}{22} \\
\hline & timber & $\mathrm{m}^{3} /$ year & $40 \operatorname{Logs}$ & $\mathrm{m}^{3} /$ year & 103 & -19 & 7 & \\
\hline & BEKP & ADT/year & 1000 Logs & $\mathrm{m}^{3} /$ year & 3700 & -500 & 133 & 1900 \\
\hline & Pine & & & & & & & 111 \\
\hline \multirow{5}{*}{ Peripheric } & ВСТМР & ADT/year & $130 \mathrm{Chip} / \mathrm{log}$ & $\mathrm{s} \mathrm{m}^{3} /$ year & 277 & 126 & 44 & \multirow{3}{*}{139} \\
\hline & Pine & & & & & & & \\
\hline & MDF & $\mathrm{m}^{3} /$ year & 300 Logs & $\mathrm{m}^{3} /$ year & 557 & 131 & 155 & \\
\hline & Pine OSB & $\mathrm{m}^{3} /$ year & 150 Logs & $\mathrm{m}^{3} /$ year & 300 & 54 & 83 & 83 \\
\hline & Electricity & $\mathrm{MWh} /$ year & 165 Chip & ton/year & 144 & 10 & 29 & 41 \\
\hline
\end{tabular}

The analysis of the data is based on the methodology proposed by Sathre and Gustavsson 2009, where the added value is a difference of inputs minus outputs, considering that workforce and capital operate in a close system, adding value to the biomass used as raw material, other raw materials such as wood adhesives, and energy (Equation 1 and 2).

$$
\begin{gathered}
V A_{T}=\left(V_{P P}+V_{M B P}+V_{E B P}\right)-\left(V_{B I}+V_{O I}+V_{E I}\right) \\
V A_{B}=V A_{T} \times \frac{V_{B I}}{V_{B I}+V_{O I}+V_{E I}}
\end{gathered}
$$

Where:

$\mathbf{V A}_{\mathbf{T}}$ - total value added

VPP - value of the primary product

$\mathbf{V}_{\text {MBP }}$ - value of the material by-products

$\mathbf{V}_{\text {EBP }}$ - value of energy by-products

$\mathbf{V}_{\mathbf{B I}}$ - value of biomass inputs

$\mathbf{V}_{\text {OI }}$ - value of other material inputs 
$\mathbf{V}_{\mathbf{E I}}$ - value of the energy inputs

$\mathbf{V A}_{\mathbf{B}}$ - value attributed to the biomass input

In addition, the added value per unit of surface was calculated by dividing the required forestry raw material volume by the MAI (Table 1), considering the log to product conversion factor presented for the description of each process. Furthermore, the surface considered for each project was the land effectively occupied by trees, and not the affected area, which includes roads, fire breaks, biodiversity protected areas, among others. Finally, the added value per investment was considered by dividing $\mathrm{VA}_{\mathrm{T}}$ by the total investment.

\section{RESULTS AND DISCUSSION}

The distinction of raw material between central or peripherical forests products is relevant to explain value added to the wood products. Wood products manufactured from central forest products, obtained at the end of the rotation, add more value to the unit of product, to the unit of biomass and to the use of the land than the peripherical products. The wood products that create more value are obtained by mechanical transformation of wood, and are destined for the construction industry, including appearance and structural timber. CLT and TMT should be considered as alternatives to add value, comparable to a remanufacturing plant to produce mouldings, appearance panels, furniture parts, among other option. However, both products are particularly interesting, since both are considered new products with a favourable market prospect, linked to the development of policies to promote wood as construction materials (Ramage et al. 2017). In addition, CLT has the highest relation between value added and capital invested, and, consequently, is not as capital intensive as the other wood products. Perhaps the pressing research question is to define the required timber grade be to fabricate these products, since the lower it is, the higher would be the profit. In this line of thought, CLT has been produced in Uruguay from low-grade logs obtained from pine thinnings, with promising results (Baño et al. 2016). LVL beams are a very attractive opportunity: technology is mature, and due to its high recovery factor, is the top product regarding added value per ha-year. Pine timber is, among the solid wood products, the lowest alternative to add value, and it should be considered a stage in the chain of value. In addition, BEKP also creates value, by efficiently converting fast-growing Eucalyptus in a demanded commodity; however, it does not add as much value per product as the solid wood products studied. Furthermore, is a capital-intensive industry, with the lowest relation observed of value added per capital invested. Pulp products, BEKP and BCTMP, present similar levels of added-value per product, but BEKP adds significantly more value per unit of biomass and per ha-year. Under Uruguayan conditions, BCTMP would necessarily be part of an integrated chain of products, and therefore, requires more land (Table 4).

The peripheric forest products are the raw material to manufacture wood products that present lower levels of value-adding, particularly by unit of biomass or per ha-year. Pine BCTMP seems an attractive option, especially regarding added value per product. MDF and OSB panels have low levels of added value, combined with a low added value per USD invested. They are capital intensive industries, which currently experience a low-price cycle for their products (FAO 2017). The fabrication of both panels would require a significant quantity of adhesives, which, in countries with no petrochemical industry such as Uruguay, are expensive. Finally, the use of wood to produce electricity is presented as an option to complement other production; as an isolated project, it would not generate enough value to be interesting (Table 4).

Table 4: Wood products: added value per unit of product, biomass, forestry land and investment.

\begin{tabular}{llcccc}
\hline Wood product & $\begin{array}{l}\text { Forest } \\
\text { product }\end{array}$ & $\begin{array}{c}\text { USD/un. USD/un. USD/per ha- } \\
\text { P }\end{array}$ & $\begin{array}{c}\text { USD/USD } \\
\text { B }\end{array}$ & year & inv. \\
\hline CLT panels & Central & 540 & 320 & 2600 & 0,70 \\
Thermally modified timber & & 490 & 420 & 1300 & 0,20 \\
LVL beams & & 270 & 120 & 4300 & 0,30 \\
Pine timber & & 220 & 140 & 1200 & 0,40 \\
BEKP & & 200 & 130 & 1500 & 0,10 \\
\hline Pine BCTMP & Peripheric & 210 & 60 & 700 & 0,30 \\
Pine MDF panels & & 100 & 30 & 200 & 0,20 \\
Pine OSB panels & & 80 & 20 & 100 & 0,10 \\
Electric energy & & 50 & 40 & 300 & 0,20 \\
\hline
\end{tabular}


To boost value added in wood products there is a clear opportunity to develop a chain of value, in a cascade-wise (from high to low value) system. This study was conducted by analysing each process isolated, and the results showed that a combination of process, by establishing coproduction lines, would potentially provide the best value to the log and to the forest land. The integration between different production processes could be achieved at different levels, e.g. extraction of hemicelluloses from strands destined to OSB production (Candan et al. 2017). Moreover, it is arguably that the lack of opportunity to co-produce valuable wood products using the whole forest biomass (central and peripheric products) is the main reason behind the slow development of the mechanical transformation of pine wood in Uruguay. To obtain 22-years-old sawlogs destined to fabricate FJ beams, CLT panels or LVL beams, pine logs from thinnings should be processed to produce OSB or MDF panels. The absence of some of the slots to allocate raw material would cause the stagnation of the whole value chain. Therefore, an industry that would use peripheric forest products is critical, perhaps not due to its value adding capacity, but because it gives stability to the forestry value chain.

Switzerland, France, Germany, among other European countries, as well as Japan, Canada or Australia, have policies to curb global warming that are aiming to replace construction materials with high levels of embodied energy, such as concrete and steel, with wood; these "wood first" regulations encourage the usage of timber as construction material (Oliver and Venables 2012, Ramage et al. 2017). From 2010 to 2015 the market share for wooden multi-storey apartments grew from 1 to $10 \%$; in Sweden, by 2020, this construction technology is expected to achieve 50\% of the market share (Toppinen et al. 2017). If this trend effectively changes the global construction industry, there would be a strong demand for wood building materials, which could consequently expand the fabrication of solid wood products in countries such as Uruguay.

Uruguay forestry resource is made of two species, pine and eucalyptus. The wood products for the construction industry that potentially add more value were analysed for pine, except for LVL beams, proposed as a combination of both species. This study was concentrated in pine because the forest resource is underutilized in Uruguay. However, there are other arguments to opt for pine as raw material for engineered wood products, as opposed to eucalyptus: it dries faster, consuming less energy; it is impregnable; and it has good adhesive ability. In addition, in Uruguay pine plantations have been pruned, and therefore, there is a significant amount of wood free of knots and related defects (Bussoni and Cabris 2010). The aptitude of Uruguayan pine timber as structural material has recently been informed (Moya et al. 2017). Arguably, the main drawback for the development of this industry is the lack of a market for the by-products of the mechanical transformation. Conversely, Eucalyptus grandis timber has also a strong potential to be used as raw material for engineered wood products, mainly due to its high ratio of modulus of elasticity to density (Piter et al. 2007, Saviana et al. 2009), and the presence of eucalyptus pulp mills in the country could potentially contribute to the development of high-valued wood products for the construction industry. In Uruguay, BEKP is obtained from a central forest product, eucalyptus pulp logs, with plantations destined exclusively for this purpose, but, in an integrated market, pulp can be produced from by-products of the mechanical transformation industry, increasing value adding Recently, the feasibility of the fabrication in China of CLT panels from eucalyptus originally cultivated for pulp production, was successfully assessed (Liao et al. 2017). This is an indication that demand could shift the production objective of fast-growing-tree plantations.

Successfully forest policies oriented the establishment of a sound forest resource in Uruguay; this study contributes knowledge for the development of wood industrialization policies. The expected global demand of wood fiber products, including construction components, tissue and packaging paper, offers an opportunity. The co-production of different wood products in a multiproduct chain of value would shift the limiting factor of operation from markets to the availability of wood (Diesen 2007).

\section{CONCLUSIONS}

The origin of the forestry biomass defines the product added value. Solid wood products for appearance or structural applications are at the top of added value list, considering value added per product, unit of biomass or unit of forest land per year. In terms of value added per product, CLT panels and TMT are clearly higher than the other products considered. LVL beams is the product that add more value to the ha-year of forestry land. BEKP is also an interesting alternative, especially regarding the value added per ha-year; as drawback, it requires very high investment. This study gave evidence that the local cost of chemicals and energy are critical for the development of a competitive OSB and MDF panels industry. In addition, logistics remains a major 
challenge in Uruguay, given the average distance from the forest plantation to the port, and the cost of internal freight. The production of electric energy is not economically feasible except by cogeneration at the same location where fuel (wood residues) are produced. Uruguay would benefit from a consolidated chain of value of wood products, in which forest products, whether central or peripherical, are allocated to maximize added value, fostering the transition to an integrated bioeconomy.

\section{ACKNOWLEDGMENTS}

The authors would like to acknowledge the assistance of several companies and institutions, based locally and overseas, for the valuable information provided and the time dedicated to the students. Finally, the authors would like to kindly thank the students for their contribution to this study.

\section{REFERENCES}

Aguirre, V.; Aunchayna, A.; Gervasini, P.; Gómez, V.; Sorhouet, E.; Tissot, J. 2017. Diseño de una planta de fabricación de MDF (Undergraduate project). Universidad de la República, Montevideo, Uruguay.

Anaya, A.; Fernández, R.; Galicia, M.; Montesinos, I. 2016. Evaluating preliminary investment feasibility. ChemEng 47-54.

Anzolabehere, M.; Nan, S. 2014. La industria de transformación mecánica de madera en Uruguay: estimación del valor agregado en la producción de madera aserrada (Undergraduate project). Facultad de Ciencias Sociales - Universidad de la República, Montevideo, Uruguay.

Ayroud, A.M. 1997. High yield and very high yield pulping, in: Pulp and Paper Manufacture. Canadian Pulp and Paper Association, Montreal, Canada, pp. 159-212.

Bajpai, P. 2015. State-of-the-Art Pulp Mills, in: Bajpai, P. (Ed.), Green Chemistry and Sustainability in Pulp and Paper Industry. Springer International Publishing, Cham, pp. 217-246.

Baño, V.; Godoy, D.; Vega, A. 2016.Experimental and numerical evaluation of cross-laminated timber (CLT) panels produced with pine timber from thinnings in Uruguay. Presented at the World Conference on Timber Engineering, Wien, Austria, p.8.

Barragán, J.; Cantera, L.; Di Pascua, I.; López, L. 2016. Tratamiento térmico de madera (Undergraduate project). Universidad de la República, Montevideo-Uruguay.

Batista, D.;Bolzon, G.; da Silva, 2016.Effect of the Brazilian thermal modification process on the chemical composition of Eucalyptus grandis juvenile wood - part 1: cell wall polymers and extractive contents. Maderas-CiencTecnol 18(2): 273-284.

Borche, A.; Gómez, L.; Mangado, I.; Marmissolle, S.; Muiño, D. 2012. Generación de energía eléctrica a partir de biomasa (Undergraduate project). Universidad de la República, Montevideo-Uruguay.

Boscana, M.; Boragno, L. 2017. Estadísticas Forestales 2017 Extracción - Producción - Consumo -Mano de Obra - Comerció exterior. Dirección General Forestal - Ministerio de Agricultura, Ganadería y Pesca, Montevideo-Uruguay.

Brizolara, M.; Crovetto, M.; Czarnievicz, M.; Díaz, M.; Riccone, V.; Vázquez, D. 2015. Diseño de una planta de fabricación de tableros de virutas orientadas (OSB) (Undergraduate project). Universidad de la República, Montevideo-Uruguay.

Bussoni, A.; Cabris, J. 2010.A financial evaluation of two contrasting silvicultural systems applicable to Pinus taeda grown in north-east Uruguay. South For 72(3-4): 163-171. 
Caamaño, A.; Esteves, M.; Formoso, M.; Laborde, G.; Lange, A. 2016. Diseño de una planta de fabricación de LVL (Undergraduate project). Universidad de la República, Montevideo.

Cabrera, M.; Cocchiararo, F.; Figares, M.; Giradello, S.; Palombo, V. 2018. Producción de pasta de celulosa quimio-termo-mecánica a partir de madera de pino (Undergraduateproject). Montevideo-Uruguay.

Candan, Z.; Shaler, S.; Paredes, J.; Edgar, R. 2017.Enhancing dimensional stability of oriented strand composites within biorefinery. Maderas-CiencTecnol 19(3): 387-398.

Clark, J. 2004. Forest policy for sustainable commodity wood production: an examination drawing on the Australian experience. Ecol Econ 50: 219-232.

Cubbage, F.; Mac Donagh, P.; Balmelli, G.; Morales-Olmos, V.; Bussoni, A.; Rubilar, R.; De La Torre, R.; Lord, R.; Huang, J.;Afonso-Hoeflich, V.; Murara, M.; Kanieski, B.; Hall, P.; Yao, R.; Adams, P.; Kotze, H.; Monges, E.; Hernández-Pérez, C.; Wikle, J.; Abt, R.; Gonzalez, R.; Carrero, O. 2014. Global timber investments and trends, 2005-2011. N Z J ForSci 44(Suppl 1):S7: 1-12.

Dhubháin, A.N.; Fléchard, M.C.; Moloney, R.; O'Connor, D. 2009.Assessing the value of forestry to the Irish economy - An input-output approach. For Policy Econ 11: 50-55.

Diesen, M. 2007.Economics of the Pulp and Paper Industry. $2^{\text {nd }}$ ed. Finnish Paper Engineers' Association, Finland.

Dieste, A. 2014. Plan de inversiones en maquinaria y equipos (No. 3). Dirección Nacional de Industrias Ministerio de Industrias, Energía y Minería, Montevideo. 32p.

Dieste, A. 2012. Programa de promoción de exportaciones de productos de madera (No. 1). Dirección Nacional de Industrias - Ministerio de Industrias, Energía y Minería, Montevideo. Uruguay. 35 p.

Dieste, A.; Clavijo, L.; Torres, A.I.; Barbe, S.; Oyarbide, I.; Bruno, L.; Cassella, F. 2016.Lignin from Eucalyptus spp. Kraft Black Liquor as Biofuel. Energy Fuels 30: 10494-10498.

Dirección General Forestal. MGAP. 2016. Extracción, producción y consumo. Ministerio de Ganadería Agricultura y PesPesca - Dirección General Forestal Uruguay <www.mgap.gub.uy> (Consulted 01/10/2017)

Dirección Nacional de Transporte. 2015. Comunicado - Precios de Referencia. Ministerio de Transporte y Obras Públicas. Uruguay <www.mtop.gub.uy>. (Consulted 01/10/2017)

FAO. 2017. FAOSTAT. <www.faostat.fao.org > (Consulted 01/10/2017)

Fardim, P.; Liebert, T.; Heinze, T. 2013. Pulp Fibers for Papermaking and Cellulose Dissolution, in: Navard, P. (Ed.), The European Polysaccharide Network of Excellence (EPNOE): Research Initiatives and Results. Springer Vienna: Vienna, pp. 253-282.

Fierro, I.; Levrini, L.; Marinello, G.; Tuana, R. 2009. Aserradero cogenerador de energía eléctrica (Undergraduate project). Universidad de la República, Montevideo- Uruguay.

García, M.P.; Juli, J.; Larratea, G.; Levy, T.; Palomas, G.; Sposaro, F. 2018. Diseño de planta de producción de paneles CLT - cross laminated timber (Undergraduate project). Montevideo- Uruguay.

Goodison, A.; Hall, P.; Jack, M.; Barry, L. 2013.WoodScape Study - Technology and Markets. SCION: New Zealand

Gullichsen, J.; Paulapuro, H. 1999.Chemical Pulping. Gummerus Printing, Jyväskylä.

Karvonen, J.; Halder, P.; Kangas, J.; Leskinen, P. 2017.Indicators and tools for assessing sustainability impacts of the forest bioeconomy. For Ecosyst 4(1): 2.

Kato, T. 1999. Japan's Wood Products Import and Forest Sector - Overview of the changes, in: Global Concerns for Forest Resource Utilization. Springer Science + Business Media, Dordrecht, pp. 337-344. 
Liao, Y.; Tu, D.; Zhou, J.; Zhou, H.; Yun, H.; Gu, J.; Hu, C. 2017.Feasibility of manufacturing cross-laminated timber using fast-grown small diameter Eucalyptus lumbers. Constr Build Mater 132: 508515.

Méndez, D.; Raffo, R.; Rivera, N.; Silva, D. 2016.Paneles del Sur (Proyecto de fin de carrera). Montevideo- Uruguay.

Moya, L.; Domenech, L.; Cardoso, A.; O’Neill, H.; Baño, V. 2017.Proposal of visual strength grading rules for Uruguayan pine timber. Eur J Wood Wood Prod 75(6): 1017-1019.

Oliver, R.; Venables, D. 2012. Efforts to promote use of wood in the EU region. Forest Industries Intelligence Limited: North Yorkshire, United Kingdom.

Onarheim, K.; Kangas, P.; Hankalin, V.; Santos, S. 2016. Understanding the cost of retroffiting CCS in a Pulp Mill - Impact of the $\mathrm{CO}_{2}$ price to the levelised cost of pulp production, in: Performance and Cost of Retroffiting CCS in Pulp and Paper Industry - Papers for Members' Reference, 2016/TR5. IEA Environmental Projects Ltd., Cheltenham, United Kingdom, p. 28.

Piter, J.C.; Cotrina, A.D.; Sosa-Zitto, M.A.; Stefani, P.M.; Torrán, E.A. 2007. Determination of characteristic strength and stiffness values in glued laminated beams of Argentinean Eucalyptus grandis according to European standards. Holz AlsRoh-Werkst 65(4): 261-266.

PROBIO. 2013. Análisis del estado del arte a nivel del sector forestal con una perspectiva global. Informe final. PNUD, Montevideo-Uruguay <www.probio.dne.gub.uy>(Consulted 01/10/2017)

Ramage, M.H.; Burridge, H.; Busse-Wicher, M.; Fereday, G.; Reynolds, T.; Shah, D.U.; Wu, G.; Yu, L.; Fleming, P.; Densley-Tingley, D.; Allwood, J.; Dupree, P.; Linden, P.F.; Scherman, O. 2017. The wood from the trees: The use of timber in construction. Renew Sustain Energy Rev 68(Part 1): 333-359.

Rasmussen, E. 2012.Industry, Commerce and Agribusiness - Russia Business Group - European Bank for Reconstruction and Development. Presented at the Northern Dimension Business Council, Saint Petersburg, p.16.

Sathre, R.; Gustavsson, L. 2009.Process-based analysis of added value in forest product industries. For Policy Econ 11: 65-75.

Saviana, J.; Sosa-Zitto, M.A.; Piter, J.C. 2009. Bending strength and stiffness of structural laminated veneer lumber manufactured from fast-growing Argentinean Eucalyptus grandis. Maderas-Cienc Tecnol 11(3): 183-190.

Sillanpää, M.; Ncibi, C. 2017a.Implementing the Bioeconomy on the Ground: An International Overview, in: Sillanpää, M., Ncibi, C. (Eds.), A Sustainable Bioeconomy: The Green Industrial Revolution. Springer International Publishing, Cham, pp. 271-315.

Sillanpää, M.; Ncibi, C. 2017b. Bioeconomy: Multidimensional Impacts and Challenges, in: Sillanpää, M.; Ncibi, C. (Eds.), A Sustainable Bioeconomy: The Green Industrial Revolution. Springer International Publishing: Cham, pp. 317-343.

Spelter, H.; Wang, R.; Ince, P. 1996. Economic Feasibility of Products from Inland West Small-Diameter Timber. No. General GTR-92.USDA-FPL.

Taylor, S.; Wilson, P. 2010. The use of cross-laminated timber in high-density affordable housing and the potential to manufacture this engineered timber product in the Dumfries \& Galloway region. CIC-Start Feasibilty Study United Kingdom.pp.1-43

Toppinen, A.; Röhr, A.; Pätäri, S.; Lähtinen, K.; Toivonen, R. 2017.The future of wooden multistory construction in the forest bioeconomy - A Delphi study from Finland and Sweden. J For Econ 31:3-10.

URUFOR. 2016. Resumen público del Plan de Manejo de Compañía Forestal Uruguaya SA. <www.urufor.com.uy> (Consulted 01/10/2017) 
Uruguay XXI. 2017. Oportunidades de Inversión - Sector Forestal. Uruguay XXI Promoción de Inversión y Exportaciones. Uruguay. p.31

UTE. 2011. Pliego de bases y condiciones para la convocatoria a interesados en la celebración de contratos de compraventa de energía eléctrica generada a partir de la biomasa (ordenanza código K42433). <www. portal.ute.com.uy> (Consulted 01/10/2017)

Wegner, T.; Skog, K.; Ince, P.; Michler, C. 2009.Uses and desirable properties of wood in the 21st century. J For 165-173. 